\title{
THE ROLE OF BUSINESS INTELLIGENCE IN DECISION PROCESS MODELING
}

\author{
Višnja Istrat ${ }^{1 *}$, Sanja Stanisavljev ${ }^{2}$, Branko Markoski $^{2}$ \\ ${ }^{1}$ Faculty of Organizational Sciences, University of Belgrade, Serbia \\ ${ }^{2}$ Faculty of Technical Sciences Mihajlo Pupin, University of Novi Sad, Zrenjanin, Serbia
}

\begin{abstract}
:
Decision making is a very significant and complex function of management that requires methods and techniques that simplify the process of choosing the best alternative. In modern business, the challenge for managers is to find the alternatives for improving the decision-making process. Decisions directly affect profit generation and positioning of the company in the market.

It is well-known that people dealt with the phenomenon of decision making in each phase of the development of society, which has triggered the need to learn more about this process. The main contribution of this paper is to show the significance of business intelligence tools and techniques as support to the decision making process of managers. Research results have shown that business intelligence plays an enormous role in modern decision process modeling.
\end{abstract}

\section{Key words:}

business intelligence, decision-making, decision.

\section{INTRODUCTION}

Decision making is the selection of one of the offered alternatives. It is an extremely complex process that should result in making the right management decisions and thus, it is essential to continuously explore and improve modern decision making methods and techniques. There is no ideal solution for the specified problem. Therefore, it should be oriented towards finding the most optimal solution. The manager should be conversant with the basic theory of the decision-making process and should possess necessary experience to make business decisions that will result in maximum profit.

There are three dimensions that determine full development of this discipline: qualitative, quantitative and information and communication aspects. These three aspects of the decision-making process fully satisfy all concepts of development of modern decision making on both theoretical and practical level.

Quantitative approach to modern decision making is defined as the basic formalism of the decision making problem (Suknović \& Delibašić, 2010). According

to (Suknović, 2001), the decision making problem is centered around the five items $(\mathrm{A}, \mathrm{X}, \mathrm{F}, \Theta, \succ)$ where:

A: final group of available alternatives (actions) that the session participant ranks with the goal of selecting the most suitable;

$\mathrm{X}$ : group of possible results that follow as a consequence of the alternative selection;

$\Theta$ : group of the state of the facts, depends on the unknown state $\theta \in \Theta$, because the consequences of the selection of the alternative $\mathrm{a} \in \mathrm{A}$ can be different;

$\mathrm{F}: \mathrm{Ax} \Theta \rightarrow \mathrm{X}$ determine for each state of the fact $\mathrm{v}$ and for each alternative a, resulting in consequence $\mathrm{x}=\mathrm{F}(\mathrm{a}, \varpi)$

$>$ : relation of weak influence to $X$, i.e. binary relation that satisfies the following conditions:
(i) $\mathrm{x}>\mathrm{y}$ or $\mathrm{y}>\mathrm{x}, \forall \mathrm{x}, \mathrm{y} \in \mathrm{X}$
(ii) $>$ Is transitive, $x>y, y>z \Rightarrow x>z$.

Relation $>$ determines the decision maker and is called the relation of the preference. Strong preference $x>y$, means that $x>y$, but not $y>z$. Relation of in- 
difference $\mathrm{x} \sim \mathrm{y}$ means that it is valid $\mathrm{x}>\mathrm{y}$ and $\mathrm{y}>\mathrm{z}$. The most frequent solution to the decision making problems is in transformation of weak item $>$ to $\mathrm{X}$ in usual item $\geq$ over real numbers with the function of utility (Centre for business decision making, 2015).

In the conditions of general problem of decision making, it is assumed that the state of the facts $\mathrm{v}$ is known, $\mathrm{X}$ is multidimensional and known for each alternative as a group of relevant values of the attribute.

Based on the level and degree of complexity of the problem, and the number of participants (Suknović \& Delibašić, 2010), modern decision making as a human phenomenon is split into the following categories:

- Individual decision making.

This decision making form is the most simplified and most often explained and used, which is confirmed by numerous references. Activities of the decision making process are dedicated to one decision maker.

- Group decision making - team work.

It is described by the higher level of the phases and activities of the decision making process. Greater number of participants (of the session) is involved in the selection of the most optimum alternative. It contains significant methods, models and up-to-date tools to support group decision making.

- Organisational decision making.

This form of decision making is described by the high level of unstructured problems the organizations face. This type of decision making is followed by numerous research experiments, but it is not yet come to systematical knowledge that would significantly improve it.

- Metaorganizational decision making.

It is the highest level of the application of systematical knowledge in the field of decision making. More information on knowledge discovery can be seen in (Guruler et al., 2010). It is practically noted at the level of one country (state), own national interest through social well-being, culture, income, etc. (Suknović \& Delibašić, 2010).

The result of successful decision making process is getting the most optimal decision for the defined topic, because there is no perfect solution. Decision is the final outcome of the decision making process, most often choosing the most acceptable alternative from the group. The process should be followed by an intuition, strong analytical tools and logical thinking. The selection of the alternative is possible by decision making techniques, decision making rules or skills. According to (Suknović \& Delibašić, 2010), the decision making moment is the most creative and most critical moment in the entire decision making process.

\section{DEVELOPMENT OF THE BUSINESS DECISION MAKING MODEL}

Data mining is the research and analysis of large amounts of data with the aim to reveal significant patterns and rules. In order to increase productivity of modern companies, the goal is to improve the organization's functions through better understanding of customers. More information on customer value management can be seen in (Verhoef et al., 2007). Data mining techniques and tools have various fields of application - law, astronomy, medicine, industry, etc. Not even one data mining algorithm has been firstly introduced for commercial purposes. More information on data mining strategy can be found in (Hornick et al., 2007). The selection of certain combination of techniques that will be used in certain situation depends on the nature of research, available data and skills and customer preferences. More information on data can be seen in (Verhoef et al., 2010). Data mining can be direct and indirect. Direct data mining explains or categorizes certain fields, like financial income, whereas indirect data mining tries to find the patterns or similarities between target groups of data with no use of certain field or collection or predefined classes.

Data mining is mostly oriented towards defining the model. The model is simply an algorithm or a set of rules that connect the collections of input (input elements) with certain goal or output elements. Regression, neural networks, decision making trees and most other techniques are oriented towards model creation. Under the right circumstances, model can result in the explanation on how output elements of certain interest, like the precise order or unsuccessful bill paying, are connected and can be predicted using the available facts. Models are also used to get the results. The result is the way of expressing the findings of the model by numbers. Results can be used to sort the list of customers from the most to least loyal, willing or not to cooperate or to pay back the loan. Data mining process is also called knowledge discovery or knowledge discovery in Databases. One of the synonyms is also knowledge creation. 
Many assignments related to intellectual, economic and business fields that will be solved by data mining can be divided into six categories:

- Classification

- Estimation

- Prediction

- Association rules

- Clustering

- Description and profiling

The first three types are the description of direct data mining, where the goal is to find certain target variables. Association rules and clustering are indirect assignments where the goal is to find the data structure, regardless of the variables value. Profiling is the descriptive assignment that can be direct or indirect. The assignment of the association rules is to determine which items go together. A typical example is grouping the items that can be bought together in shopping at a supermarket - market basket analysis.

Supermarket chains use association rules to plan the timetable of items on the shelves or in the catalogue so that the items that can be bought together are most often together on the shelves. They are used to identify chances for cross-selling and designing of attractive packaging or grouping of products or services. It is a simple approach on how to create the rules from large databases. If two items, i.e. computer and web camera are often bought together, we can produce two association rules:

- Buyers that buy computer can also buy web camera with probability of P1

- Buyers that buy web camera can also buy computer with probability of $\mathrm{P} 2$

The assignments and the process of data mining can be different. Depending on data mining results, the assignments can be:

- Exploratory data analysis: in databases large amounts of data are at disposal. This data mining assignment has two purposes: search of knowledge that customer demands and data analysis. These techniques are interactive and visual for the customers.

- Descriptive modeling: describes all data, including models for the whole probability of data distribution, split of multidimensional space into groups and models that describe the relations between variables.

- Predictive modeling: this model allows prediction of values of some variables more than known values of other variables.
- Data mining: this assignment has been used to find the hidden patterns and the rules in cluster. There are different sizes at disposal in clusters. The goal of this is to reveal "how it is best to find the rules". This can be achieved by using the rules for induction and many other techniques in data mining algorithms. This is called clustering of algorithms.

- Research of the content: the primary goal of this assignment is finding the data set that is often used for audio/video tasks, as well as photos. Such data mining is similar to those that are of interest in dataset.

The most frequently used data mining techniques are:

- Decision making trees and their rules,

- Non-linear regressions and classification methods,

- Methods based on examples,

- Models of graphical dependence of the probability,

- Relational models of learning, etc.

In general, we classify these data mining methods as: Online analytical processing (OLAP), classification, clustering, association rules, temporary data mining, time-sheet analysis, space research, web research, etc. More information on classification can be found in (Grabmeier \& Lambe, 2007).

These methods use different types of algorithms and data. The source of data can be data warehouse, database, regular or textual file. Algorithms can be statistical, based on the decision making tree, neural networks, generic algorithms, etc. In general, data mining algorithms are completely dependent on two factors:

- type of datasets used

- demands of customers

Knowledge Discovery Process includes raw data of choosing data mining algorithm, as well as processing of data results. More information on data mining models can be seen in (Johansson et al., 2004). There are programs that are called assistants for knowledge discovery (Intelligent Discovery Assistants - IDA), that help in the application of valid knowledge in the research process. These assistants provide three benefits to the users:

- Systematic validation of process for knowledge discovery, 
- Effective ranking of valid processes on different criteria, that help in choosing the suitable option and

- Infrastructure for knowledge sharing, that leads to externalization of networks.

There have been attempts to make this process automatic and design the general tool for data mining that uses business intelligence while selecting data and data mining algorithms, and to a certain extent, knowledge discovery.

Knowledge management and data mining are still in the development phase and they represent interesting areas for researchers. Although there is an integrative framework for knowledge management in the context of marketing, there are critical research challenges that should be devoted considerable attention. More information about data mining for marketing can be seen in (Berry \& Linoff, 2004). Some of them are connected to data mining techniques and knowledge discovery process, while others are related to knowledge management. Data research through data mining techniques is an interactive process of learning similar to other processes of acquiring knowledge, like scientific research. Selection of data mining algorithms, hypothesis forming, model evaluation and remodeling are the key components of the research process. Since the cycle of attempts and failures for progressive adopting are made of the most valuable knowledge through data mining, the aspect of learning through experiments can be suitable for that. One of the research challenges is to make sure that this process is multi-structured, and therefore to increase the productivity of data mining trials. Furthermore, it is needed to manage the knowledge in the sense that it outlines organizational borders and further distributes towards the other partners.

Another challenge is multiple classifications when the customer belongs to more than one category. There is the case of web mining. The Internet is getting the primate as a new channel for the goods distribution, product promotion, transaction management and coordination of business processes and it becomes a valuable and suitable source of data about customers. More information on management can be seen in (Draker, 2003). However, multiple formats of data and distributive nature of knowledge on the Web are the challenge for collecting, revealing, organizing and knowledge management in the way that is suitable for providing support to business decision making. More information on decision support system can be seen in (Kotsiantis, 2011).

\section{GROUPS OF DATA THAT WILL BE TESTED}

There is the table with three types of data from different sources. Those data are then processed and real and important information for the defined problem is obtained. By application of association rules, knowledge is the final outcome of the decision making process. The structure and size of research data, as well as the proper use of business intelligence tools influence the creation of the improved model of business decision making. More information on business intelligence can be found in (Guster \& Brown, 2012).
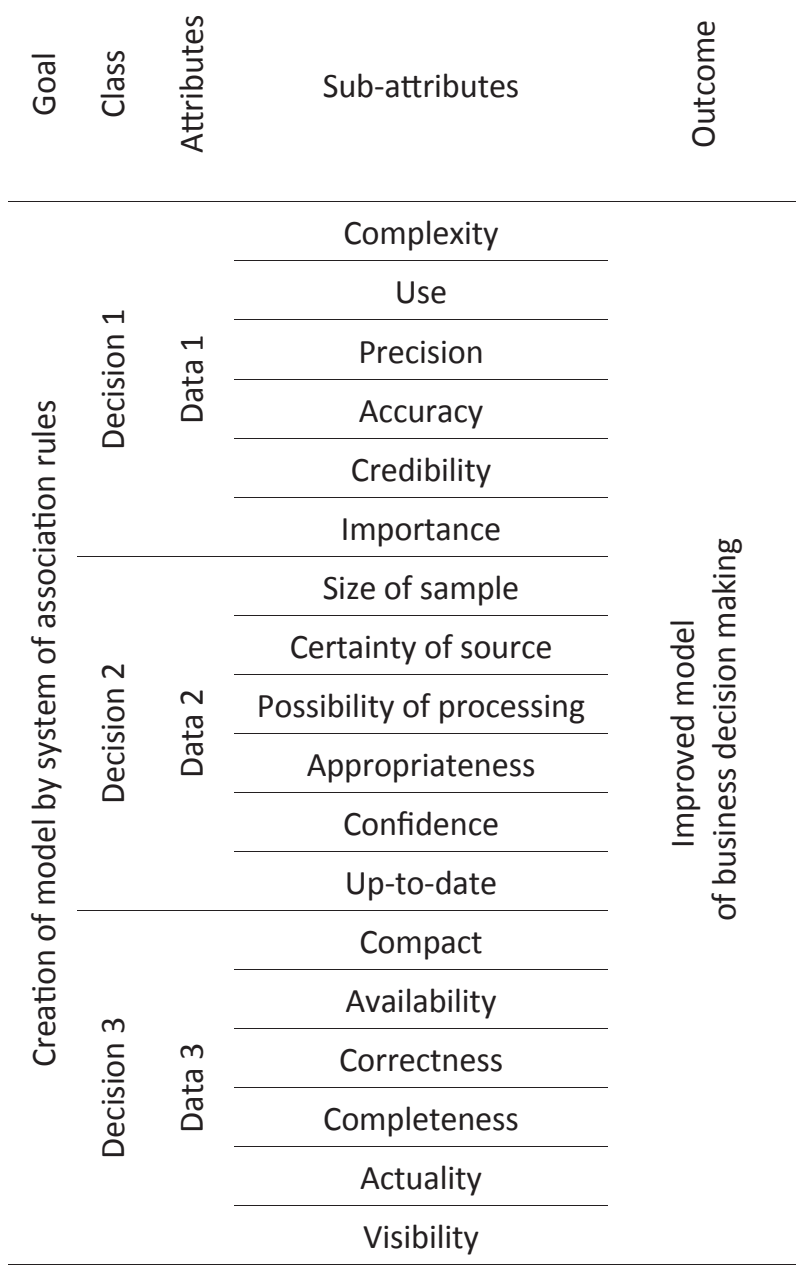

Table 1. Suggestion of groups of data for testing

According to (Suknović, 2001), there are three dimensions that determine the complete development of modern decision making. These are: qualitative, quantitative aspect and information-communication aspect. Research of all three aspects is the most optimal. Data will be shown in quantitative aspect, as given in the table, and will be processed by numerical 
values. Business intelligence methods and techniques will be applied. Attributes and sub-attributes will be described, as shown in the table, in order to ensure the qualitative aspect of modern decision making. Description of the results will ensure the qualitative aspect. The application of software and visual overview of data will show the information-communication aspect of modern decision making. Table 1 shows the groups of test data with three classes and attributes, each of which contains six sub-attributes. During the research, it is possible to modify the number of classes, attributes and sub-attributes (Mihailović, 2004). Depending on the number of data and relevant criteria, the final data structure of research will be defined.

Sub-attributes are values that relate to attributes and are defined by managers based on the significance of certain segments needed for conducting research. Sub-attributes in Table 1 are not of the same importance, and the way of structuring of multiple problem active manager participation in the process of its solving, are in the model of defining the weight of users' criteria. More information can be seen in (Čupić \& Suknović, 2008).

Aggregation of criteria (sub-attributes) has been conducted based on the analysis of various current research, opinions from data mining experts and numerous discussions in order to generate the most relevant criteria for data values whose influences cannot be neglected: complexity, accuracy, size of the sample, etc. (table 1).
For determination of values of criteria in multicriteria decision making, defining of vector coefficients has been used. Criteria defined in the form of vector of coefficients represent the exchange or mutual relation between the criteria. Certain hierarchical structure of problem of comparison of criteria between each other is the matrix of evaluation. For the purpose of testing the group, the software made at the Faculty of Organizational Sciences in Belgrade has been used. More information on software can be found on the web page of the Centre for business decision making.

Table 2 shows the comparison of the criteria subattributes from the example of future research. Matrix of evaluation is square dimensions, equal to number of criteria in model. There is no evaluation of criteria between each other and items are visible at the main diagonal. The other values are imported as a result of comparison of each criterion separately. Only direct values are imported, while inverted values are defined on their own, in this example through software.

Solution to the problem has the following steps:

Matrix of comparison should be adjusted in pairs, so as to put the unit in the field where each criteria is compared to each other. In order to count the sum of elements in each column of adjusted matrix, with following equation:

$$
l_{j}=\sum_{i=1}^{n} P_{i j}, \mathrm{j}=\overline{1, n}
$$

\begin{tabular}{|c|c|c|c|c|c|c|c|c|c|c|}
\hline \multirow[t]{2}{*}{ Level 4} & \multirow[b]{2}{*}{ Complexity } & \multirow[b]{2}{*}{ Usefulness } & \multirow[b]{2}{*}{ Preciseness } & \multirow[b]{2}{*}{ Aceurasy } & \multirow[b]{2}{*}{ Credibirit } & \multirow[b]{2}{*}{ Significanc } & \multirow[b]{2}{*}{ Size } & \multirow[b]{2}{*}{ Confidence } & \multirow[b]{2}{*}{ Processing } & \multirow[b]{2}{*}{ Suitability } \\
\hline & & & & & & & & & & \\
\hline complexity & 1.00 & 0.20 & 0.14 & 0.50 & 0.25 & 5.00 & 1.00 & 3.00 & 0.50 & 0.25 \\
\hline Usefulness & 5.00 & 1.00 & 3.00 & 0.50 & 0.33 & 0.11 & 0.50 & 7.00 & 0.33 & 7.00 \\
\hline Preciseness & 7.00 & 0.33 & 1.00 & 0.17 & 0.17 & 0.20 & 8.00 & 3.00 & 7.00 & 9.00 \\
\hline Accuracy & 2.00 & 2.00 & 6.00 & 1.00 & 0.14 & 0.13 & 3.00 & 8.00 & 1.00 & 0.13 \\
\hline credibility & 4.00 & 3.00 & 6.00 & 7.00 & 1.00 & 3.00 & 0.14 & 2.00 & 0.11 & 8.00 \\
\hline Significance & 0.20 & 9.00 & 5.00 & 8.00 & 0.33 & 1.00 & 0.50 & 0.13 & 7.00 & 3.00 \\
\hline Sample size & 1.00 & 2.00 & 0.13 & 0.33 & 7.00 & 2.00 & 1.00 & 7.00 & 0.50 & 9.00 \\
\hline confidence & 0.33 & 0.14 & 0.33 & 0.13 & 0.50 & 8.00 & 0.14 & 1.00 & 0.17 & 6.00 \\
\hline Processing & 2.00 & 3.00 & 0.14 & 1.00 & 9.00 & 0.14 & 2.00 & 6.00 & 1.00 & 0.25 \\
\hline Suitability & 4.00 & 0.14 & 0.11 & 8.00 & 0.13 & 0.33 & 0.11 & 0.17 & 4.00 & 1.00 \\
\hline Data 1 & Data 2 & Data 3 & & & & & & & & \\
\hline
\end{tabular}


Lis the sum of elements of adjusted column,

$\mathrm{P}$ is the value of the criteria.

To divide each element of the column with the sum of values of that column, with the following equation:

$$
h_{i j}=P_{i j} \div l_{j}, i=\overline{1, n}, j=\overline{1, n}
$$

Counting the sum of elements and then determine the arithmetic mean of each row. Column that has the middle values is actually the normalized vector.

$$
W_{i}=\sum_{j=1}^{n} h_{i j}, i=\overline{1, n}
$$

$\mathrm{W}$ is the column of values of criteria elements in row,

$\mathrm{H}$ is the value of criteria.

Middle value is determined by data in column W that splits with number of criteria and is shown in row $t$, because it is a square matrix.

$$
t_{j}=w_{j} \div n, j=\overline{1, n}
$$

In this manner, the value of each criterion in the model is calculated. Vector of coefficients is normalized and the sum of elements is equal to one. More information about the process of defining the vector of coefficients can be found in (Čupić \& Suknović, 2008).

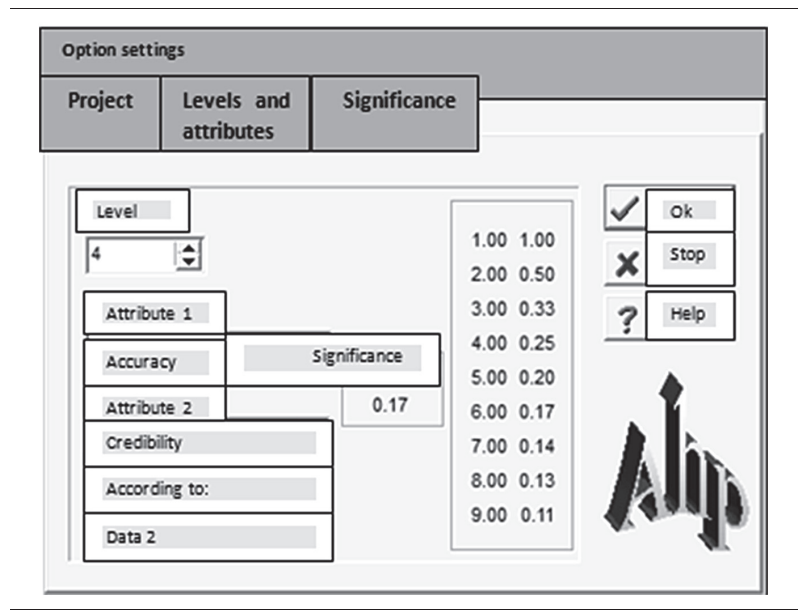

Figure 1. Dialog box for defining the level and attributes of model

Figure 1 shows the initial step of defining the options for creating the level and attributes inside each level of the defined model. It is defined which method of multicriteria decision making will be used in re- search (Promethee, Electre or AHP). For realization of this example, the method of analytical-hierarchical process (AHP) has been used.

The method of the analytical-hierarchical process (AHP) was defined by Thomas Saaty in the 1970s. AHP represents the tool and the analysis of decision making, created with the help of managers in solving the complex problems with multiple criteria and greater number of managers. AHP is based on the concept of balance used for determination of the overall relative significance of the group of attributes, activities or criteria, and it relates to the analyzed problem of decision making.

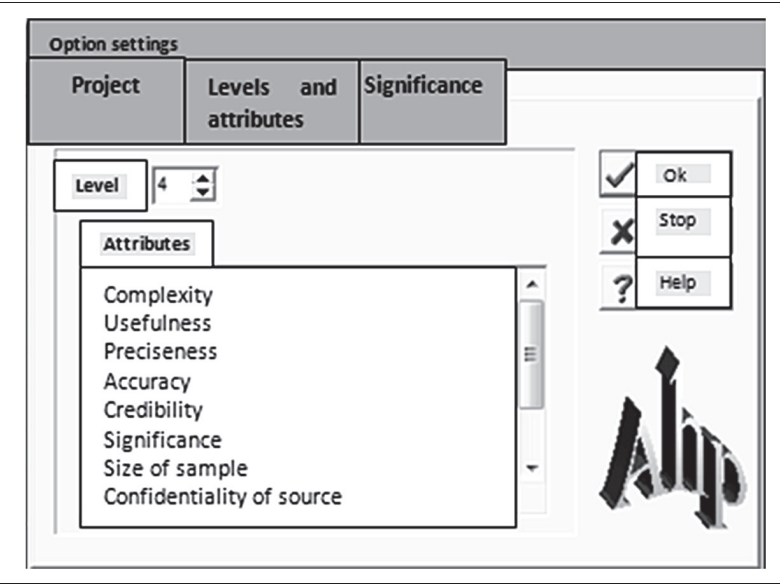

Figure 2. Dialog box for defining the vector of coefficients

Figure 2 shows the dialog box for assigning the significance of each criterion related to others in the predefined table. The predefined table with nine options is Saaty's most famous scale for assigning the weights that is confident in solving real problems of business systems. Saaty's scale for conversion of linguistic statements while comparing the significance of pairs of criteria is put as a standard due to its simplicity. The manager most often defines the relations between the criteria, and therefore the subjective aspect of the decision making is apparent.

Figure 3 provides an overview for the analysis of hierarchy between the defined levels of the model. There is the influence and interdependence of the defined criteria of business decision making. Visual overview enables data mining to the user and adaptation of the existing elements of the model. More information on data mining trends can be seen in (Kriegel et al., 2007; Krüger et al., 2010; Bramer, 2007). There is the influence of all sub-attributes on all data, the influence of all three types of data on three models of 


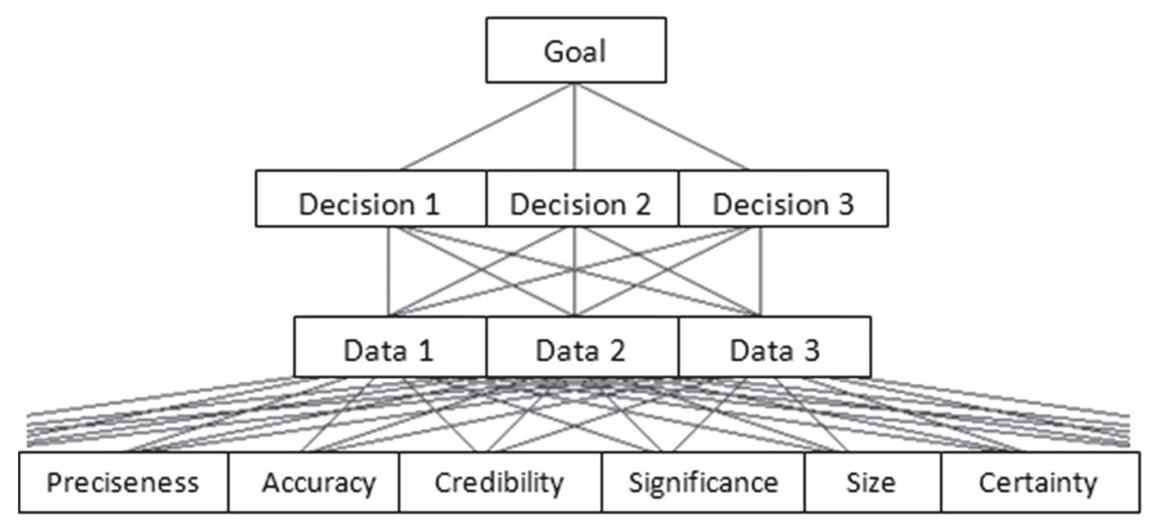

Figure 3. Overview of segments of the defined model hierarchy

decisions, and their overall influence on the goal of the model - creating the improved model of business decision making.

After data processing by AHP method, there is the graphic with defined vectors of weight of criteria coefficient. Based on the graphical overview of the model, it could be easy to see the criteria that has high vector of coefficients and, therefore, bigger value. Based on the given example, it is easy to see the significance of data (with defined vector 0.14 ), accuracy (0.122) and possibility of processing $(0.121)$.

The plan is to include the axiom of transitivity in future research. According to (Čupić \& Suknović, 2008), the axiom of transitivity states: if $A$ is bigger than $\mathrm{B}$, and $\mathrm{B}$ is bigger than $\mathrm{C}$, than it follows that $\mathrm{A}$ is bigger than $\mathrm{C}$.

$\mathrm{A}>\mathrm{B}$ and $\mathrm{B}>\mathrm{C}=>\mathrm{A}>\mathrm{C}$
As could be seen in Table 1, axiom of transitivity could be applied to the choice of class with the most suitable dataset according to the defined criteria by most optimal decision.

If the class "Decision 1" is more significant (acceptable, numerically bigger) than class "Decision 2", and class "Decision 2" is more significant that "Decision 3 ", it follows that class "Decision 1" is more significant than "Decision 3". In this manner, the ranking of the final results and classes would be easier, which would lead to the solution to the defined model of business decision making. More information on classes can be found in (Gupta et al., 2010).

If the axiom of transitivity is successfully applied to the example of classes and attributes, and if the application is scientifically verified, it follows that it can be successfully used for choosing and comparing the sub-attributes. According to Figure 4, deductive method leads to the following conclusion: if sub-attribute "accuracy" has bigger numerical value

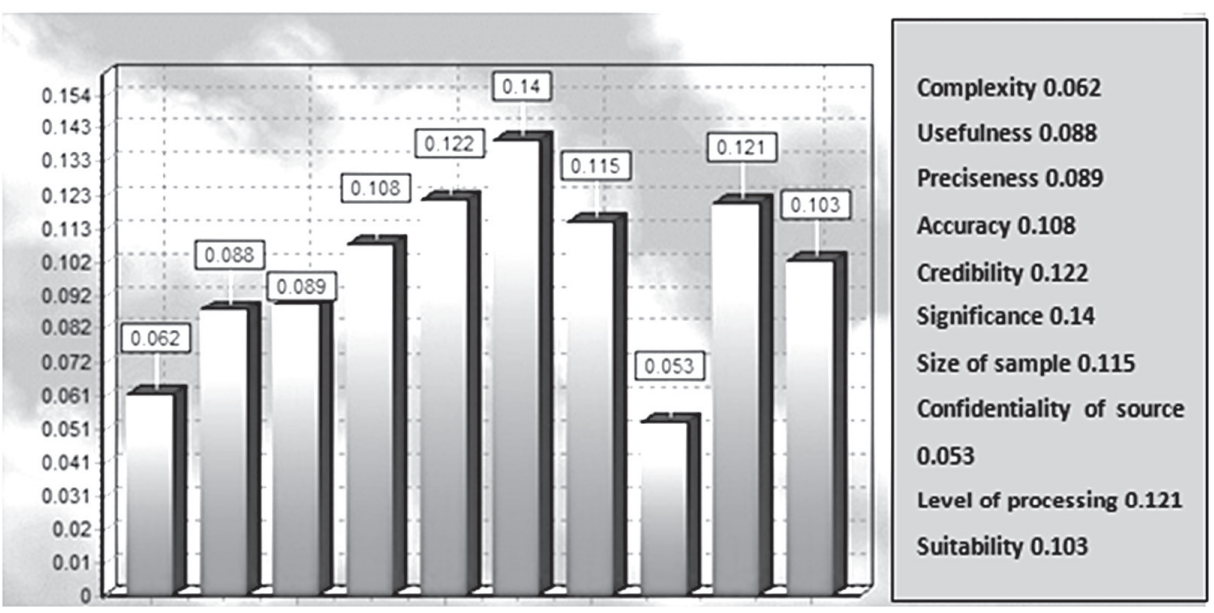

Figure 4. Criteria levels defined by AHP method 


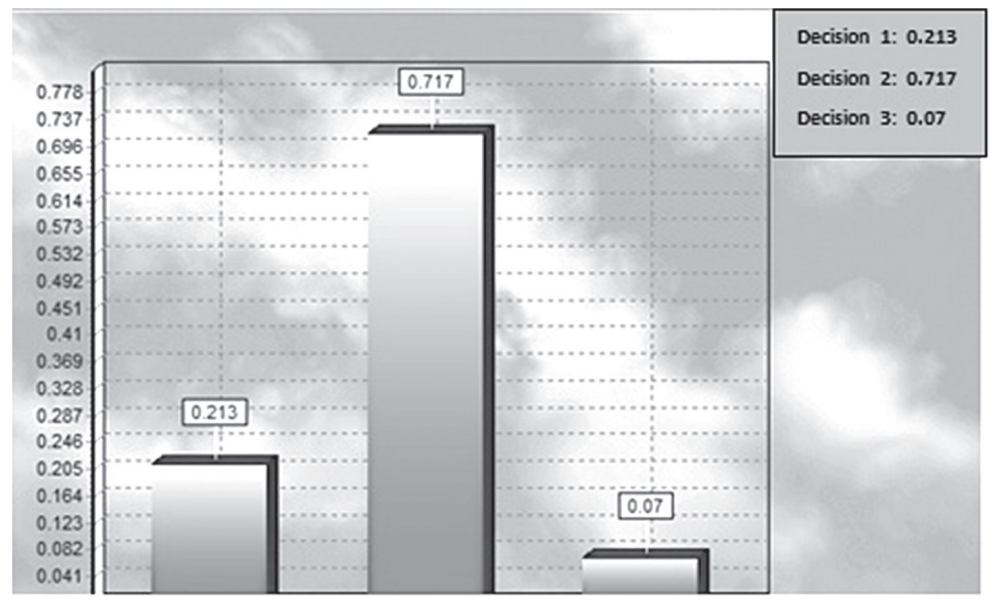

Figure 5. Graphic of criteria level for the most optimal decision of the model

(defined according to the vector of coefficients) than sub-attribute "precision", and "precision" has bigger value than sub-attribute "source confidence" than it follows that sub-attribute "accuracy" has bigger value than sub-attribute "source confidence". More information can be seen in (Istrat, 2014).

Figure 5 shows the defined vector of coefficients at the decision level. Decision 2 has the biggest vector (0.717) and the biggest value for the goal of the model. Here, the axiom of transitivity can be applied: if the vector of Decision 1 is bigger than the vector of Decision 2, and the vector of Decision 2 is bigger than vector of Decision 3, then it follows that the vector of the Decision 1 is bigger that the vector of the Decision 3. Decision 1 is of greater importance than the Decision 3.

\section{CONCLUSION}

Based on the current research of domestic and foreign experts in the field of business intelligence, it has been shown that this area has vast potential but is still relatively unrevealed in some segments of application. Therefore, it is the challenge for the researchers and the area where significant scientific and professional benefits can be provided. Innovative research approach to business intelligence is characterized by knowledge and creativity, as well as the use of modern data mining software. Modern scientific methods analyze the results and offer recommendations and guidelines for further research.

The primary motivation for development of this model is to show the significance that business intelligence has in the process of decision making for modern management. The aim is to create the business decision making model that can be applicable to business systems of different aspects and for commercial purposes. The significance of business intelligence for creating the model is shown, which can increase the effectiveness of the decision making process in management.

\section{REFERENCES}

Berry, M.J.A., \& Linoff, G. (2004). Data mining techniques: For marketing, sales, and customer relationship management. Indianapolis: Wiley.

Bramer, M. (2007). Principles of Data Mining. Springer: London.

Centre for business decision making. (2015). Decision-making. Retrieved May 5, 2015, from www.odlucivanje.fon.rs

Čupić, M, \& Suknović, M. (2008). Odlučivanje. Beograd: FON. In Serbian.

Draker, P. (2003). Moj pogled na menadžment : izbor iz dela o menadžmentu Pitera Drakera. Novi Sad: Adizes. In Serbian.

Grabmeier, J.L., \& Lambe, L.A. (2007). Decision trees for binary classification variables grow equally with the Gini impurity measure and Pearson's chi-square test. International Journal of Business Intelligence and Data Mining, 2(2), 213-226. doi:10.1504/IJBIDM.2007.013938

Gupta, A., Li, J., Conradi, R., Rønneberg, H., \& Landre, E. (2010). Change profiles of a reused class framework vs. two of its applications. Information and Software Technology, 52(1), 110-125. doi:10.1016/j.infsof.2009.08.002.

Guruler, H., Istanbullu, A., \& Karahasan, M. (2010). A new student performance analyzing system using knowledge discovery in higher educational databases. Computers \& Education, 55(1), 247-254. doi:10.1016/j.compedu.2010.01.010. 
Guster, D., \& Brown, C.G. (2012). The Application of Business Intelligence to Higher Education: Technical and Managerial Perspectives. Journal of Information Technology Management, 23(2), 42-62.

Hornick, M.F., Marcadé, E., \& Venkayala, S. (2007). Java data mining: Strategy, standard, and practice: a practical guide for architecture, design, and implementation. Amsterdam: Elsevier-Morgan Kaufmann.

Istrat, V. (2014). Pristupni rad doktorske disertacije, Unapredjenje modela poslovnog odlučivanja sistemom asocijativnih pravila. Beograd: FON. In Serbian.

Johansson, U., Nilsson, L., \& Koenig, R. (2004). Accuracy vs. comprehensibility in data mining models. Proceedings of the Seventh International Conference on Information Fusion (pp. 295-300). Retrieved May 5, 2015, from http://www.fusion2004.foi.se/papers/IF04-0295.pdf

Kotsiantis, S.B. (2011). Use of machine learning techniques for educational proposes: a decision support system for forecasting students' grades. Artificial Intelligence Review, 37(4), 331-334. doi:10.1007/s10462-011-9234-x.

Kriegel, H., Borgwardt, K.M., Kröger, P., Pryakhin, A., Schubert, M., \& Zimek, A. (2007). Future trends in data mining. Data Mining and Knowledge Discovery, 15(1), 87-97. doi:10.1007/s10618-007-0067-9
Krüger, A., Merceron, A., \& Wolf, B.A. (2010). Data Model to Ease Analysis and Mining of Educational Data. Retrieved May 5, 2015, from http://educationaldatamining.org/ EDM2010/uploads/proc/edm2010_submission_9.pdf

Mihailović, D. (2004). Metodologija naučnih istraživanja. Beograd: FON. In Serbian.

Suknović, M. (2001). Razvoj metodologije podrške grupnom odlučivanju. Doktorska disertacija, Fakultet organizacionih nauka, Beograd. In Serbian

Suknović, M., \& Delibašić, B. (2010). Poslovna inteligencija i sistemi za podršku odlučivanju. Beograd: FON. In Serbian.

Verhoef, P.C., \& van Doorn, J., \& Dorotic, M. (2007). Customer value management: An overview and research agenda. Journal of Research in Management, 2, 51-68.

Verhoef, P.C., Venkatesan, R., McAlister, L., Malthouse, E.C., Krafft, M., \& Ganesan, S. (2010). CRM in Data-Rich Multichannel Retailing Environments: A Review and Future Research Directions. Journal of Interactive Marketing, 24(2), 121-137. doi:10.1016/j.intmar.2010.02.009.

\section{ULOGA POSLOVNE INTELIGENCIJE U SAVREMENOM ODLUČIVANJU}

\section{Rezime:}

Odlučivanje je veoma značajna i kompleksna funkcija menadžmenta koja zahteva metode i tehnike koje olakšavaju proces izbora jedne od više ponuđenih alternativa. U savremenom poslovanju veliki izazov za menadžment jeste pronaći alternativne načine za poboljšanje procesa poslovnog odlučivanja. Odlučivanje utiče direktno na stvaranje profita i pozicioniranje kompanija na tržištu.

Činjenica je da su se u svakoj fazi razvoja društva ljudi bavili fenomenom odlučivanja, što uslovljava širenje znanja o ovom procesu. Glavni doprinos ovog rada jeste da ukaže na značaj alata i tehnika poslovne inteligencije kao podrške menadžmentu u procesu odlučivanja. Rezultati ukazuju na ogroman značaj poslovne inteligencije u savremenom odlučivanju.

\section{Ključne reči:}

poslovna inteligencija, odlučivanje, odluka. 